\title{
A Comparison of Learning and Teaching Styles - Self-Perception of IT Students
}

\author{
Zlatko J Kovačić \\ The Open Polytechnic of New Zealand, Wellington, New Zealand
}

Zlatko.Kovacic@openpolytechnic.ac.nz

Executive Summary

This paper presents the results of an empirical study of the learning styles of a group of computing students and the teaching styles of their tutors at The Open Polytechnic of New Zealand. This study of learning styles is based on Kolb's learning model and the Felder-Soloman learning style instrument. To identify how close students' learning styles match the teaching styles of their tutors we have used two indicators: the self-perception of the students about the proximity of their learning styles and the teaching styles of their tutors and a Euclidean distance measure between students' and tutors' learning preferences. Using survey data and the learning styles instrument results we identify the differences between the learning and teaching styles. Both indicators show consistent and significant differences between the learning and teaching styles, in the way students and their tutors perceive and understand information. Finally we make recommendation to tutors on how to bridge this gap and address the learning styles of their students.

Keywords: Learning styles, Teaching styles, Felder-Solomon Index of Learning Styles, Computer concepts, Distance education.

\section{Introduction}

The accelerated growth of the education sector in the last two decades could be partly contributed to the Internet based communication tools that were widely used to deliver courses and support students. Increasing demand for quality continuous education from society and the economy is putting pressure on academic staff to maintain high level of services despite of increasing number of students. At the same time budgetary restrictions and requests from governments to increase efficiency in the tertiary sector force academics to continually review the quality of the learning material they produce and to accommodate teaching styles and developments in technology to the changing learning styles of students. We believe that a mismatch between the learning styles of students and the teaching styles of tutors might lead to poor educational performance and a low retention of students on courses. So far, qualitative analysis or anecdotal evidence has been used to illustrate this mismatch between learning and teaching styles. Therefore we think there is a need for quantitative experimental research that will address this mismatch between learning and teaching styles.

Material published as part of this journal, either on-line or in print, is copyrighted by Informing Science. Permission to make digital or paper copy of part or all of these works for personal or classroom use is granted without fee provided that the copies are not made or distributed for profit or commercial advantage AND that copies 1) bear this notice in full and 2) give the full citation on the first page. It is permissible to abstract these works so long as credit is given. To copy in all other cases or to republish or to post on a server or to redistribute to lists requires specific permission from the publisher at Publisher@InformingScience.org
This paper presents results of an empirical study of the learning styles of a group of Computer Concepts course students enrolled in the second semester of 2003 at The Open Polytechnic of New Zealand. The Open Polytechnic is the only specialist provider of open and distance education in New Zealand. Computer Concepts is a 
compulsory course that is part of the New Zealand Diploma in Business. The course uses electronic discussion forums for communication and peer-to-peer and tutor support. Participation in the discussions is an integral part of the assessment regime.

The main objective of our research is to identify the diversity of learning and teaching styles among Computer Concepts students and their tutors. More specifically the data gathered for this paper was used to address the following four questions:

- do the students' learning styles match the IT tutors' learning styles?

- could the self-perception of students about how close the teaching style matches their learning style be used as an indicator of the proximity between the teaching and learning styles?

- $\quad$ are the results of Euclidean distance between students and the average IT tutor learning style scores consistent with the results based on the self-perception of students?

- do the results of Euclidean distance between teaching and learning styles based on the learning styles instrument correlate with the students' self-perception of proximity?

The learning styles of students and tutors and their differences will be the main focus of this study. Other authors such as for example Ford and Chen (2001) studied the match/mismatch between teaching and learning styles. However, they have used different learning style model and instrument and therefore their results and not directly comparable with the results from this paper.

The first section gives a brief overview of learning styles models, summarising the Kolb and Felder-Silverman learning style models. In the second section the learning styles instrument is described. In the next section data and methodology are discussed. The fourth section presents the learning styles results along with critical comments. Finally we make some suggestions on how to accommodate the different learning styles of students and how to modify teaching styles to effectively use available communication tools.

\section{Learning Styles Models}

The most common framework used for description and explanation of learning styles models is Curry's 'Onion' Model (Curry, 1983). This meta model attempts to define and illustrate relationship between learner's personality, cognitive styles, learning styles and learning strategies. There is an alternative generalisation of learning styles models other than the classic Curry's Model developed by Gordon and Bull (2004) and applicable only to 4-cycles types of learning styles models.

An excellent systematic overview of the main learning style models based on the Curry's 'Onion' Model is given in Atkins et al (2001). Different approaches have been used to model and label a student's learning style, from those based on social interaction and instructional and environmental preferences to information processing and personality levels. Among these approaches the information processing approach (the middle layer of the Curry's model) is of particular interest in the context of this paper. The reason for this is that the models which belong to this layer are more stable than the others, and they do not interact directly with the environment, though they are modifiable by learning strategies (Atkins, Moore, Sharpe, \& Hobbs, 2001). The most dominant learning cycles models are the 4-stage learning cycles model. Among them the most cited and used to identify learners' preferences is Kolb's experiential learning cycles model (Kolb, 1984) and the Felder-Silverman model (1988).

The Kolb model uses the learner's experience as a corner stone or starting point in the learning process. Learners are perceived as passing through four stages of learning. Initially they are experimenting with the topic accumulating enough concrete experience to be able to reflect in the 
second stage on the observation gathered in the concrete experimenting stage. As a result of reflective activities learners derive abstract concepts and make generalisations in the third, abstract conceptualisation stage. Finally, new concepts are subject to testing to see if they provide a solid explanation in new situations. In other words, learners begin a new learning cycle, gathering new evidence, concrete experience. Though learners are moving through each stage they tend to use a specific learning mode. Therefore we can describe them as a learner with a preference for a particular mode. By looking at the quadrants, Kolb identified four types of learners in this model: Diverger (creative, generates alternatives), Assimilator (defines problems, creates theoretical models), Converger (practical applications, makes decision) and Accomodator (takes risks, gets things done), as we have labeled them in Figure 1. We can also identify these learners by the type of question they would ask while they learn: "Why?", "What?", "How?" and "What if?"

Initially the Felder-Silverman learning style model was developed as a five dimensional model, with the following dimensions: Perception, Input, Processing, Understanding and Organisation. Later they omitted the Organisation dimension, because Felder (1993) believes that the best approach to teaching undergraduates is always inductive and therefore his learning styles instrument does not differentiate between inductive and deductive learners.

Both the Kolb and Felder-Silverman models belong to the information processing category of learning style models and are based on the same educational philosophy of John Dewey, which emphasises the nature of experience as of fundamental importance in education.

There is a close relationship between the Felder-Silverman model and the Kolb learning style model. The Processing dimension, with active and reflective poles in the Felder-Silverman model matches the same Processing dimension in Kolb's model. Also, the Perception dimension in the Felder-Silverman model with sensing and intuitive poles matches the same Perception dimension in Kolb's model as we have illustrated in Figure 1.

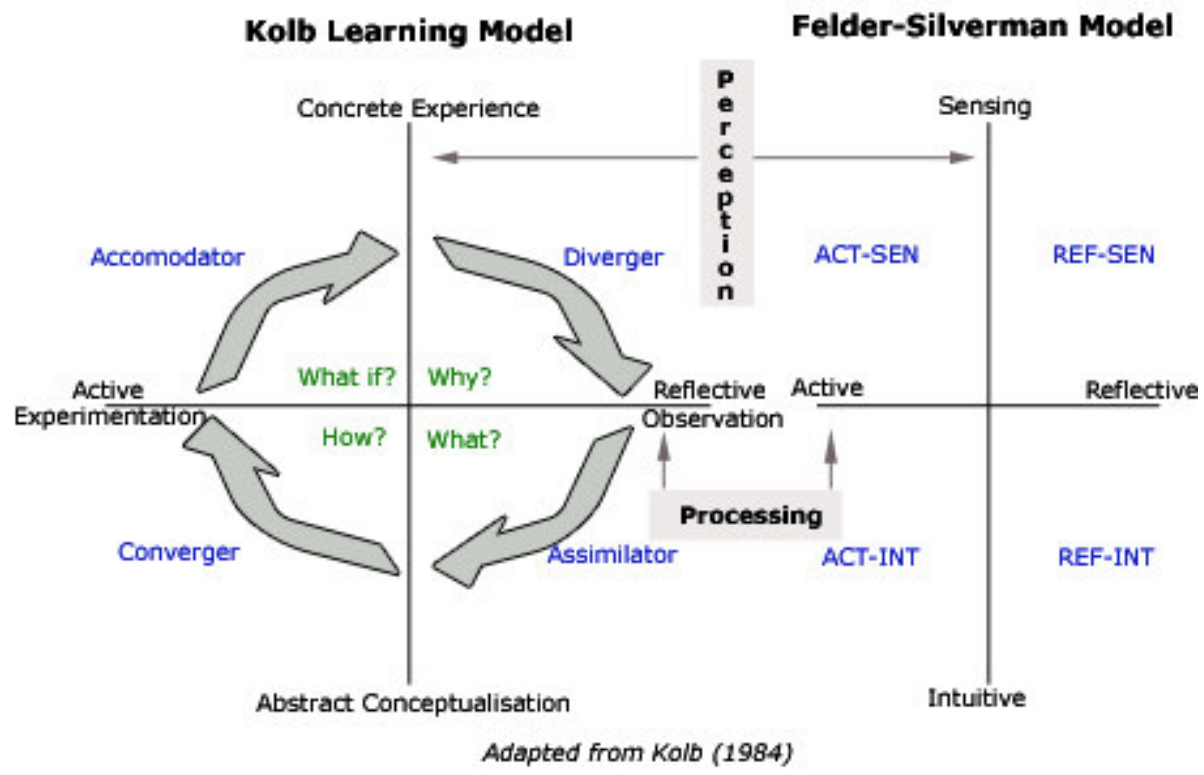

Figure 1: Kolb and Felder-Silverman learning models 


\section{Learning Styles Instrument}

While there are several different instruments for measuring individuals' learning styles (see for example, Hickcox, 1995, for an excellent critical overview of adult learning style inventory models), in this paper we used the instrument developed by Felder and Soloman (2003), known as the Index of Learning Styles (ILS), which is a simple test based on experiential learning theory (Felder-Silverman learning style model in particular).

The reasons we have opted for this particular learning style instrument are as follows: Firstly, it covers all four learning styles dimensions and is based on a sound theoretical model. Secondly, the instrument has been widely tested and used successfully in helping to guide the design, development and use of effective learning environments. Thirdly, this instrument is simple to use and the results obtained from this study are easy to interpret and can be applied easily. Fourthly, this instrument has good validation results (Zywno, 2003a), which makes this instrument reliable in detecting preferred learning styles among students.

The Felder-Solomon ILS questionnaire is constructed as a bi-polar instrument across four dimensions: Processing (with poles: active/reflective), Perception (sensing/intuitive), Input (vis$\mathrm{ual} / \mathrm{verbal}$ ) and Understanding (sequential/global). The dichotomous learning style dimensions of this model are continuous and not discrete categories. This means that the learner's preference on a given scale does not necessarily belong to one of the poles. It may be strong, moderate, or almost non-existent.

According to Felder and Silverman (1988) active learners are described as those who learn by actively trying things and collaborating with others. Reflective learners' preferences are for thinking rather than trying things through and they prefer working alone. Sensing learners prefer learning facts and procedures while intuitive learners are innovative and oriented more toward concepts, theories and meanings. Visual learners prefer visual representations such as pictures, diagrams and charts while verbal learners prefer written or spoken explanations. Sequential learners are linear, orderly and learn in small incremental steps while global learners are holistic thinkers who learn in large leaps.

The instrument consists of 11 questions for measuring each of the four dimensions, and thus a total of 44 questions. Each question along a dimension is designed to determine if a respondent tends to belong to one category or another on that dimension. It does so by asking the respondent to choose only one of two options where each option represents each category. For example the Input dimension has two categories: Visual and Verbal. One of the Input dimension questions in the instrument is "When I think about what I did yesterday, I am most likely to get (a) a picture or (b) words". A respondent who chooses (a) is one who tends to be a visual learner while one who chooses (b) tends to be a verbal learner. A respondent is classified as belonging to a particular category, for example, visual instead of verbal on the Input dimension, if he or she chooses more of the options that correspond to those of visual learners. Since there are 11 questions for each dimension, a respondent is always classifiable along each dimension. The range of data for each dimension is from 0 to 11 . Obviously there are 16 possible combinations, or types of learner in this model.

\section{Data}

We administered the Felder-Solomon (2003) Index of Learning Styles instrument as an integral part of a compulsory Assessed Project. We asked students to identify their learning style by replying to the online questionnaire at the North Carolina State University web site, host of the ILS. At the time when we asked them to complete this online questionnaire we had 174 students enrolled in the course. From these 174 students 117 submitted the Assessed Project (67\%). After submitting the Assessed Project only 92 students continued their study, while rest of the class withdrew 
from the course. From 117 students who submitted the Assessed project, 92 of them, i.e. 79\%, completed the online questionnaire and sent in their learning style results. At the same time, 9 IT tutors completed the same Felder-Solomon ILS questionnaire.

At the end of the course, but before the final exam we asked the students to help us improve the course by providing a feedback on eleven questions (one of the question was: "On a scale of 1 to 5 ( 1 being the least close and 5 the most close) how would you rate how close the teaching style matched your learning style". A total of 92 emails requesting the feedback were sent to students and 48 of these emails received a reply (response rate of 52\%). Unfortunately 5 of the students who provided their learning style results did not provide feedback and vice versa.

\section{Results}

The Felder-Solomon learning styles frequencies of the Open Polytechnic of New Zealand Computer Concepts students are listed in Table 1 along with the results of a number of published studies relevant to this study. In all these studies the same learning style model and instrument have been used in the various departments. The four columns in Table 1 labeled Active, Sensing, Visual, and Sequential show the percent of students who are active, sensor, visual and sequential learner.

Table 1: Comparison of student's learning styles frequencies

\begin{tabular}{|c|c|c|c|c|c|c|}
\hline Study & Active & Sensing & Visual & Sequential & $\begin{array}{l}\text { Number of } \\
\text { participants }\end{array}$ & Institution \\
\hline $\begin{array}{l}\text { Kovačić (this } \\
\text { study) }\end{array}$ & $50 \%$ & $86 \%$ & $82 \%$ & $58 \%$ & 92 & $\begin{array}{l}\text { The Open Polytechnic } \\
\text { of New Zealand }\end{array}$ \\
\hline Zywno (2003b) & $61 \%$ & $65 \%$ & $88 \%$ & $63 \%$ & 338 & $\begin{array}{l}\text { Ryerson Polytechnic } \\
\text { University }\end{array}$ \\
\hline $\begin{array}{l}\text { Fowler et al. } \\
\quad(2002)\end{array}$ & $58 \%$ & $65 \%$ & $83 \%$ & $61 \%$ & 69 & $\begin{array}{l}\text { School of Engineering, } \\
\text { Murdoch University }\end{array}$ \\
\hline $\begin{array}{l}\text { Fowler et al. } \\
\quad(2002)\end{array}$ & $67 \%$ & $67 \%$ & $76 \%$ & $55 \%$ & 116 & Murdoch University \\
\hline $\begin{array}{c}\text { Zywno \& } \\
\text { Waalen (2002) }\end{array}$ & $53 \%$ & $66 \%$ & $86 \%$ & $72 \%$ & 87 & $\begin{array}{l}\text { Ryerson Polytechnic } \\
\text { University }\end{array}$ \\
\hline $\begin{array}{c}\text { Zywno \& } \\
\text { Waalen (2002) }\end{array}$ & $69 \%$ & $59 \%$ & $80 \%$ & $67 \%$ & 858 & $\begin{array}{l}\text { University of Western } \\
\text { Ontario }\end{array}$ \\
\hline Ng et al. (1999) & $50 \%$ & $78 \%$ & $82 \%$ & $62 \%$ & 60 & Faculty of IT of QUT \\
\hline $\begin{array}{l}\text { Montgomery } \\
(1995)\end{array}$ & $67 \%$ & $57 \%$ & $69 \%$ & $71 \%$ & 143 & University of Michigan \\
\hline
\end{tabular}

Based on comparative data, it appears that Computer Concepts students are less active (the lowest active frequency of 50\% only), but more sensing than participants from other academic institutions (the highest sensing frequency of $86 \%$ ). The result indicates that approximately $86 \%$ of Computer Concepts students prefer the sensing mode of perceiving information in comparison to only $14 \%$ of students who prefer the intuitive mode. From Table 1 we see that the closest match with the Computer Concepts students learning styles profile are those of ABAP programming students at Faculty of Information Technology of Queensland University of Technology (there are some discrepancies in the sensing and sequential frequencies only). 
The study of tutors' learning style was based on the assumption that tutors teach partially based on their own individual learning style (this was supported by findings presented in Stitt-Gohdes, Crews, and McCannon, 1999). However, tutors could also integrate theories of student-centered learning and constructivism, even if it is not the way they learned or prefer to learn. Data for the Open Polytechnic IT tutors are shown in Table 2 along with results of several other published studies. Data presented indicate that most academics are intuitors (percents from the Sensing column in Table 2 are less than 50\%), but the majority of students are sensors (percents from the Sensing column in Table 1 are well over 50\%). Consequently, if staff teach according to their learning styles then a mismatch may exist with the average student.

Table 2: Comparison of tutor's learning styles frequencies

\begin{tabular}{|c|c|c|c|c|c|c|}
\hline Study & Active & Sensing & Visual & Sequential & $\begin{array}{c}\text { Number of } \\
\text { participants }\end{array}$ & Institution \\
\hline Kovačić & $56 \%$ & $44 \%$ & $78 \%$ & $22 \%$ & 9 & $\begin{array}{c}\text { The Open Polytechnic } \\
\text { of New Zealand }\end{array}$ \\
\hline $\begin{array}{c}\text { Zywno } \\
(2003 \mathrm{~b})\end{array}$ & $38 \%$ & $42 \%$ & $94 \%$ & $35 \%$ & 48 & $\begin{array}{c}\text { Ryerson Polytechnic } \\
\text { University }\end{array}$ \\
\hline $\begin{array}{c}\text { Fowler et al. } \\
(2002)\end{array}$ & $27 \%$ & $36 \%$ & $73 \%$ & $45 \%$ & 11 & $\begin{array}{c}\text { School of Engineering } \\
\text { Murdoch University }\end{array}$ \\
\hline
\end{tabular}

The comparison of student and staff results from the ILS survey are shown in Figure 2. Based on learning styles frequencies we defined the dominant student as active, sensing, visual and sequential while the dominant IT tutor is active, intuitive, visual and global. In other words students are different from their tutors in the way they perceive and understand information. However, both students and tutors prefer to input and process the information in the same way (visually and actively).

To identify how different the student learning style is from the IT tutor learning style we have calculated the mean value of the IT tutors' learning style scores. The tutor who scored the average score was labeled as an average IT tutor. Table 3 contains mean scores and mean differences in scores between students and IT tutors. The table also contains the value of the F-ratio and P-value

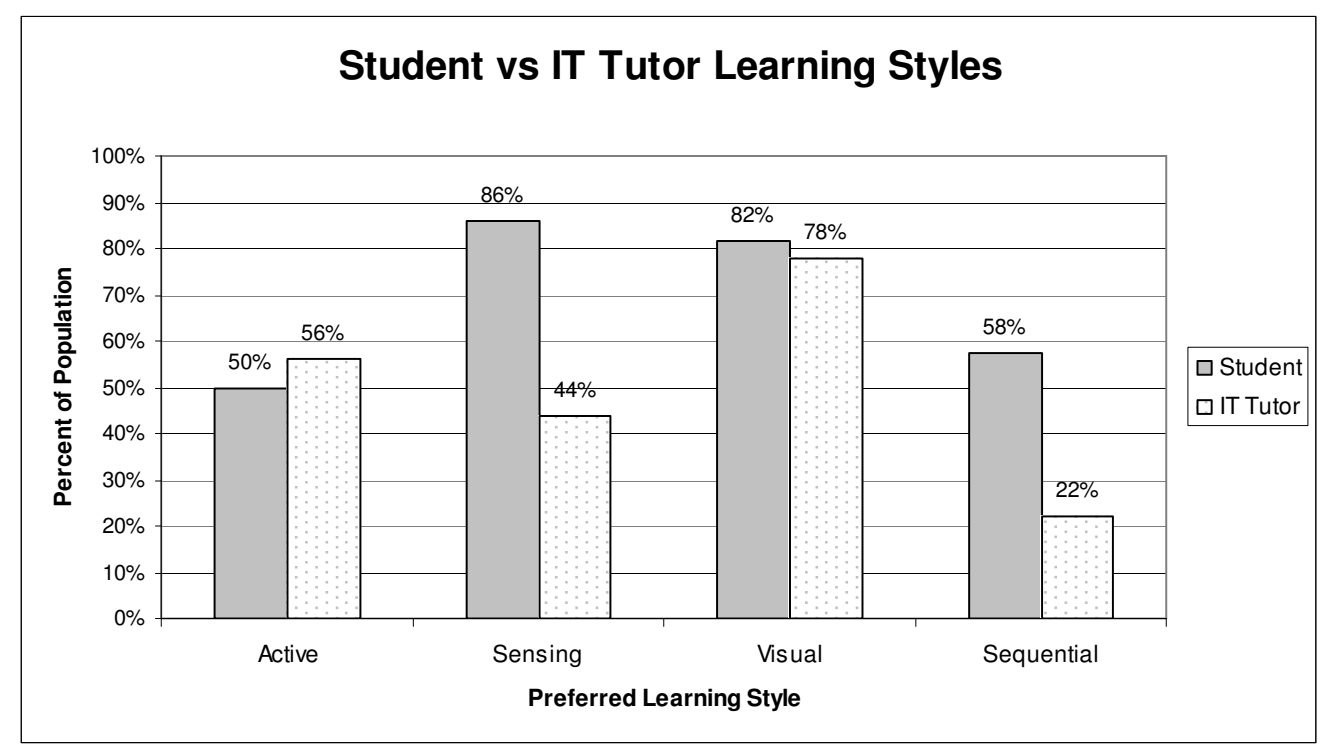

Figure 2: Student vs. IT tutor learning styles 
Table 3: Comparison of Felder's learning styles scores between students (S) and IT tutors (T)

\begin{tabular}{|l|c|c|c|c|c|}
\hline \multicolumn{1}{|c|}{ Dimension } & Mean score(S) & Mean score(T) & $\begin{array}{c}\text { Mean differ- } \\
\text { ence }\end{array}$ & F-ratio & P-value \\
\hline Active score & 5.49 & 5.11 & 0.38 & 0.25 & 0.62 \\
Reflective score & 5.51 & 5.89 & -0.38 & 0.25 & 0.62 \\
\hline Sensing score & 8.15 & 4.56 & 3.59 & $19.73^{* *}$ & 0.00 \\
Intuitive score & 2.85 & 6.44 & -3.59 & $19.73^{* *}$ & 0.00 \\
\hline Visual score & 7.42 & 7.89 & -0.47 & 0.31 & 0.58 \\
Verbal score & 3.58 & 3.11 & 0.47 & 0.31 & 0.58 \\
\hline Sequential score & 5.90 & 3.44 & 2.46 & $9.57 * *$ & 0.00 \\
Global score & 5.10 & 7.56 & -2.46 & $9.57 * *$ & 0.00 \\
\hline
\end{tabular}

** F-ratio is significant at the 0.01 level.

for each mean difference. The P-value indicates the likelihood of obtaining a difference as large as that observed if it occurred simply from randomness in the data. A low P-value implies that we would probably not observe such a large difference from purely random data and the difference must be the result of some systematic effect. By convention, we usually label any difference with a P-value of 0.05 or less as meaningful, that is, statistically significant.

Both the mean scores for the Perception (sensing/intuitive) and Understanding (sequential/global) dimensions show high F-ratio values, which are statistically significant. The P-values for these scores differences are less than 0.00 (positive but less than $0.0005 \%$ ). These are very low and well below the conventional cutoff point of 0.05 , so the differences are statistically significant and we can state with a high level of confidence that students' scores are different from scores of their tutors on both dimensions. In cases of Processing (active/reflective) and Inputting (visual/verbal) dimensions the P-values were very high (well above 0.05 ), so neither difference was statistically significant.

We used two instruments to measure how close the IT tutors' learning style matched those of students. As we said before, we are using the tutors' learning style as a proxy for their teaching styles because very often teaching style of tutors reflects their own learning styles. The first instrument (we have labeled it as self-perception) is based on a questionnaire where we asked students to self-evaluate how close their IT tutors teaching style matched their own learning style. The second instrument is based on a statistical distance measure, the well known Euclidean distance. Based on the Felder-Solomon scores of IT tutors we have calculated the mean scores for each dimension of the Felder-Solomon ILS. The scores for each student were then used to calculate the Euclidean distance between the student and the average IT tutor. When the Euclidean distance moves closer to zero it means that the student learning style is a closer match to the teaching style of the average IT tutor and vice versa. We expected that the self-perception of students about how close their learning style matched that of their IT tutors would be congruent with the results based on Euclidean distance measure. In other words if they perceived their learning style match was closer to the IT tutors teaching style (numerically closer to 5 on the Likert scale) then the Euclidean distance between them and tutors should tend toward zero.

The Felder-Solomon ILS was completed by 92 students. However, self-evaluation results were received from 48 students only ( 5 of them did not submit the result of the Felder-Solomon ILS questionnaire). Therefore we have used self-evaluation results and learning styles scores for this 
subset of 43 students. At the same time, we have calculated Euclidean distances for the larger set ( $N=92$ students) and used them to see how robust our result based on a smaller data set was.

Since the dominant IT tutor is active, intuitive, visual and global our results in the Table 4 show an almost perfect match. On average the self-evaluation of 43 students reveals that active, intuitive, visual and global learners think that the IT tutors teaching style matches their learning style.

Table 4: Proximity of learning and teaching styles

\begin{tabular}{|l|c|c|c|c|c|c|c|c|c|}
\hline \multirow{2}{*}{ Dimension } & \multicolumn{3}{|c|}{ Self-perception (N=43) } & \multicolumn{3}{c|}{$\begin{array}{c}\text { Euclidean distance } \\
\text { (N=43) }\end{array}$} & \multicolumn{3}{c|}{$\begin{array}{c}\text { Euclidean distance } \\
\text { (N=92) }\end{array}$} \\
\hline \multirow{3}{*}{ Processing } & ACT & REF & F-ratio & ACT & REF & F-ratio & ACT & REF & F-ratio \\
\cline { 2 - 11 } & 3.47 & 2.67 & 7.85 & 10.25 & 8.81 & 2.85 & 8.89 & 8.07 & 1.91 \\
& & & $(0.01)$ & & & $(0.10)$ & & & $(0.17)$ \\
\hline Perception & SEN & INT & F-ratio & SEN & INT & F-ratio & SEN & INT & F-ratio \\
\cline { 2 - 11 } & 3.00 & 3.50 & 0.46 & 9.55 & 7.33 & 1.16 & 8.87 & 6.08 & 12.06 \\
& & & $(0.50)$ & & & $(0.29)$ & & & $(0.00)$ \\
\cline { 2 - 11 } & VIS & VRB & F-ratio & VIS & VRB & F-ratio & VIS & VRB & F-ratio \\
\cline { 2 - 11 } & 3.21 & 2.33 & 5.91 & 8.78 & 11.96 & 10.97 & 8.01 & 10.56 & 12.57 \\
& & & $(0.02)$ & & & $(0.00)$ & & & $(0.00)$ \\
\hline Understanding & SEQ & GLO & F-ratio & SEQ & GLO & F-ratio & SEQ & GLO & F-ratio \\
\cline { 2 - 10 } & 3.04 & 3.07 & 0.02 & 9.70 & 9.05 & 0.54 & 9.37 & 7.27 & 13.87 \\
& & & $(0.91)$ & & & $(0.47)$ & & & $(0.00)$
\end{tabular}

Their average self-evaluation scores are higher than the corresponding average scores of reflective, sensing, verbal and sequential learners. The differences are statistically significant for Processing (active/reflective) and Input (visual/verbal) dimension.

If we use Euclidean distances the results are almost the same as the previous one based on the student's self-perception, with one exception - reflective learners seem closer to the IT tutors. We shall comment on this discrepancy later. Since the average Euclidean distances of intuitive, visual and global learners are smaller than the corresponding average Euclidean distances for sensing, verbal and sequential learners (difference is statistically significant in case of Input domain only) we can conclude that these results are consistent with the previous one based on students' selfevaluation. Students' perception of teaching and learning style is an unbiased indicator of proximity between IT tutors teaching styles and students' learning styles.

As we mentioned before the Euclidean distance for reflective learners is smaller than that for active learners, though we expected the opposite. The reason for this is as follows. We have used learning styles scores for 9 IT tutors. Five of them are active learners (56\%) and 4 are reflective (44\%). Therefore the dominant IT tutor is an active learner. However, the average learning style scores for the Processing dimension are 5.1 (active) and 5.9 (reflective). Since the reflective score is higher than the active this would suggest that the average IT tutor is reflective. This is the only mismatch between the dominant and average IT tutor in terms of their learning styles. The main reason for such a discrepancy is due to the small sample size (nine IT tutors only).

In case of the larger data set all the differences among averages of Euclidean distances are statistically significant except the first one (Processing dimension: active and reflective scale) suggesting that active, intuitive, visual and global learners are closer to an average IT tutor. 
To test the hypothesis that the results of Felder-Solomon ILS scores correlate with selfperceptions on proximity between teaching and learning styles by students, we have calculated the Pearson's correlation coefficients between the students' evaluation scores and the different dimensions of the Felder-Solomon ILS and presented them in Table 5. The figure between the brackets shows P-value, i.e. the level of significance. The P-value indicates the likelihood of obtaining a correlation coefficient as large as that observed if it occurred simply from randomness in the data. A low P-value implies that we would probably not observe such a large correlation coefficient from purely random data and the coefficient must be the result of a linear relationship between observed series.

Table 5: Correlation between learning styles dimensions and proximity of learning and teaching styles

\begin{tabular}{|l|c|c|c|c|}
\hline & ACT & SEN & VIS & SEQ \\
\hline Teaching Style matches & $0.27^{* *}$ & -0.06 & $0.30^{*}$ & -0.15 \\
Learning Style & $(0.08)$ & $(0.69)$ & $(0.05)$ & $(0.35)$ \\
\hline $\begin{array}{l}\text { Euclidean distance between } \\
\text { student and average IT tutor }\end{array}$ & $0.27^{*}$ & $0.67^{* *}$ & $-0.31^{* *}$ & $0.41^{* *}$ \\
& $(0.08)$ & $(0.0)$ & $(0.04)$ & $(0.01)$ \\
\hline
\end{tabular}

For the first variable (how close teaching style matches student learning style) all the correlation coefficients are with expected sign. Since the dominant IT tutor is an active, intuitive, visual and global learner we would expect a positive correlation between the active and visual scores and the students' perception of how close their learning style matches the dominant IT teaching style. On the other hand, for sensing and sequential scores we would expect a negative correlation because the IT tutor learns is the opposite way (intuitive and global). However, only the correlation coefficients for active and visual scores show some statistical significance (8\% and 5\%, respectively) and the level of relationship is quite low, about 0.27 and 0.30 , respectively.

The smallest distance between students and tutors (in terms of how close teaching style match learning style) is for intuitive students. The highest + /- correlation is for sensing/intuitive scores and Euclidean distance, which stress the importance of Perception (sensing/intuitive) dimension for learning styles research.

Finally, the correlation between the Euclidean distance and self-perception scores was negative (0.23 ) as expected, but statistically not significant (at the 0.13 level), most probably because of the small sample size. Thus the hypothesis that the results of the Felder-Soloman ILS correlates with the self-perception of students on how closely the teaching style matches their learning style preferences was rejected.

\section{Implication for Teaching}

In his 1993 seminal article Felder emphasized that students whose learning styles are compatible with the teaching style of s tutor tend to retain information better, obtain better grades and maintain a greater interest in the course. The identified mismatch between students' learning preferences and the dominant teaching style of tutors should be addressed and changes should be made in the current teaching practice. Felder gave advice to academics to balance between opposite poles in each learning dimension. However, to some extent students should be also exposed to the teaching style which is different from their preferences to prepare them for the real world. 
We have used a list of Felder's recommendations to address the different learning styles among Computer Concepts students, illustrating each suggestion with an example from the course:

1. To bridge the gap in Perceiving and Understanding dimension between them and students, tutors should provide more examples (sensing) to illustrate how to design a business application in a step-by-step (sequential) manner. This is quite important because there is a large $(60 \%)$ practical component covering word processing, the use of spreadsheets, database management and the Internet.

2. Numerical examples (sensing) for functions and formulas (intuitive) in spreadsheets and databases, should be provided with sufficient time for trial (active) and absorbing (reflective) the information.

3. Since discussion forums are written discourse per se, tutors should use attachments with screen shots (visual) of important steps (sequential) in designing a business application. Alternatively PowerPoint presentation with animated slides or multimedia elements and speaker's notes could enrich the learning experience because of students' preference toward visual input of information.

4. Each important step (sequential) in business application design (word processing, spreadsheeting and database) should be discussed in the forums (active/reflective). Teamwork and cooperation (active) should be encouraged.

5. Tutors can help students to develop learning skills in other areas by developing assignments (in-course and the final exam) that address all or most of learning styles. This could be achieved by creating holistic, complex assignments, which contain activities for each learning preferences.

\section{Conclusion}

This paper has presented the results of an empirical study of the learning styles of students and tutors. We have identified the differences in learning and teaching styles using the FelderSoloman Index of Learning Styles. More specifically, we have found that they are different in two dimensions of the Felder-Silverman learning styles model, i.e. in the Perceiving and Understanding dimension. We have also shown that students' self-perception about the proximity between their learning styles and tutors teaching styles was quite unbiased. This finding was supported by using another proximity measure - the Euclidean distance between the learning preferences of students and tutors. We would like emphasis that these findings are based on the assumption that teaching style of tutors reflects their own learning style.

Awareness about learning styles is very important both to academic staff and students. Students will understand why the tutors are using different teaching approaches on the course and how they can benefit from that. Academic staff should recognise the variety of learning styles among students and adjust their teaching style to take account of this. The results presented in this paper also send a clear message to the course designers to create a learning environment that will support the construction of knowledge in our students.

This research sets the foundation for future work on learning styles in the Open Polytechnic of New Zealand. Further work is planned to extend the data set over different courses and programs and to join with institutions in other countries in collaborative research. We believe that IT students are differently positioned in their learning preferences compared to students in other disciplines as was shown for marketing students (Jaju \& Kwak, 2000) or for community collage students (Jones, Reichard \& Mokhtari, 2003). We also believe that cross-cultural differences in learning styles of students are significant as was found by Jaju, Kwak and Zinkhan (2002). Fi- 
nally, we are planning to test the impact of standard demographics on the learning styles and to test the academic performances of students with different learning styles.

\section{Acknowledgements}

I would like to thank John Green, Senior Lecturer in the School of Information Science and Humanities at the Open Polytechnic of New Zealand for valuable comments on the first draft of this paper. I also take this opportunity to thank those anonymous Conference reviewers for their time and extremely valuable work which helped me to improve the final version of this paper. However, the author should be held responsible for any remaining errors.

\section{References}

Atkins, H., Moore, D., Sharpe, S., \& Hobbs, D. (2001, June). Learning style theory and computer mediated communication. ED-MEDIA 2001, Tampere, Finland. Retrieved June 10, 2003 from http://oufcnt5.open.ac.uk/ Hilary_Atkins/edmedia.htm

Felder, R. M. (1993). Reaching the second tier - Learning and teaching styles in college science education. Journal of College Science Teaching, 78 (7), 674-681. Retrieved June 10, 2003 from http://www.ncsu.edu/felder-public/Papers/Secondtier.html

Felder, R. M., \& Silverman, L.K. (1988). Learning and teaching styles in engineering education. Engineering Education, 78 (7), 674-681.

Felder, R.M. \& Soloman, B. A. (2003). Index of learning styles questionnaire. Retrieved October 10, 2003 from http://www.engr.ncsu.edu/learningstyles/ilsweb.html

Ford, N. \& Chen, S.Y. (2001). Matching/mismatching revisited: An empirical study of learning and teaching styles. British Journal of Educational Technology, 32 (1), 5-22

Fowler, L., MCGill, D., Armarego, J., \& Allen, M. (2002, July). Quantitative learning conversations: Constructivism and its application to learning in an engineering environment. Proceedings of the HERDSA Conference, Perth, Western Australia.

Gordon, D. \& Bull, G. (2004, March). The Nexus explored: A generalised model of learning styles. $15^{\text {th }}$ International Conference of Society of Information Technology \& Teacher Education, Atlanta, Georgia, USA.

Hickcox, L. K. (1995). Learning styles: A survey of adult learning style inventory models. In R. R. Sims, \& S. J. Sims (Eds.), The importance of learning styles (pp. 25-46). USA: Greenwood Press.

Jaju, A. \& Kwak, H. (2000). Learning preferences of marketing students. In J. P. Workman, Jr. \& W. D. Perreault, Jr., (Eds.), Marketing in a time of great change, (pp. 243-250). Chicago: American Marketing Association.

Jaju, A., Kwak, H. \& Zinkhan, G. M. (2002). Learning styles of undergraduate business students: A crosscultural comparison between the US, India, and Korea. Marketing Education Review, 12 (2), 49-60.

Jones, C., Reichard, C. \& Mokhtari, K. (2003). Are students' learning styles discipline specific? Community College Journal of Research and Practice, 27 (5), 363-375.

Kolb, D. (1984). Experiential learning: Experience as the source of learning and development. PrenticeHall: Englewood Cliffs, NJ.

Ng Pui, C.S, Chan, T., \& Andrews, R. (1999). Learning to program in ABAP: An empirical study of IT students' learning styles. Proceedings of the 3rd Annual SAP Asia Pacific Institutes of Higher Learning Forum, SAP Australia Pty Ltd, 89 - 101. Retrieved June 10, 2003 from http://www.business.vu.edu.au/sapconf/paper8_Ng.doc

Stitt-Gohdes, W. L., Crews, T. B., \& McCannon, M. (1999). Business teachers' learning and instructional styles. Delta Pi Epsilon Journal, 41(2), 71-88. 
Zywno, M. S. (2003a). A contribution to validation of score meaning for Felder-Soloman's index of learning styles. Proceedings of the 2003 American Society for Engineering Education Annual Conference \& Exposition, Section 2351. Retrieved October 10, 2003 from http://www.ncsu.edu/felderpublic/ILSdir/Zywno_Validation_Study.pdf

Zywno, M. S. (2003b). Student learning styles, web use patterns and attitudes toward hypermedia-enhanced instruction, Proceedings of the 33rd ASEE/IEEE Frontiers in Education Conference, Session S1D, November 5-8, 2003, Boulder. Retrieved December 5, 2003 from http://fie.engrng.pitt.edu/fie2003/papers/1134.pdf

Zywno, M. S. \& Waalen, J.K. (2002). The effect of individual learning styles on student outcomes in technology-enabled education. Global Journal of Engineering Education 6(1), 35- 44. Retrieved June 10, 2003 from http://www.eng.monash.edu.au/uicee/gjee/vol6no1/Zywno.pdf

\section{Biography}

Dr Zlatko J Kovačić is a Senior Lecturer in the School of Information Science and Humanities at the Open Polytechnic of New Zealand. Zlatko has a varied academic background and research interests, ranging from core interests relating to IT careers, learning and teaching, to eCommerce, eLearning, time series analysis, multivariate analysis and Web (data) mining. His current research is focused on cognitive processes in distance education using computers and communications technologies. 